\title{
Factors Affecting Satisfaction of Parents at Pediatric Emergency Department Admission
}

\section{Muhammet Mesut Nezir ENGİN ${ }^{1 *}$, Ramazan Cahit Temizkan², Merve Aslantaş ${ }^{3}$, Nursel Büyük ${ }^{4}$ Önder Kılıçaslan ${ }^{5}$, Yunus Şengün ${ }^{6}$, Kenan Kocabay ${ }^{7}$}

\footnotetext{
${ }^{1 *}$ Research Assistant, Düzce University Faculty of Medicine, ${ }^{2}$ Assistant Professor, Düzce University Faculty of Medicine, ${ }^{3}$ Research Assistant, Düzce University Faculty of Medicine, ${ }^{4}$ Research Assistant, Düzce University Faculty of Medicine, ${ }^{5}$ Assistant Professor, Düzce University Faculty of Medicine, ${ }^{6}$ Research Assistant, Düzce University Faculty of Medicine, ${ }^{7}$ Professor, Doctor, Düzce University Faculty of Medicine.
} doktormesut@hotmail.com

*Corresponding Author: Muhammet Mesut Nezir ENGIN, Düzce Üniversitesi Tıp Fakültesi Hastanesi Çocuk Hastalıkları Polikliniği.

Abstract

Aim: The purpose of this study is; to reveal the demographic characteristics of the patients, to assess parental satisfaction and to establish the factors that affect parental satisfaction, and the reasons for which parents are satisfied or dissatisfied.

Material \& Methods: A total of 186 patients who were admitted to Düzce University Hospital Pediatric Emergency Department between February 1st 2017 - April 1st 2017, and accepted to fill out the questionnaire were taken to the study.

Results: During the period of the study, 6110 patients were admitted to a pediatric emergency department. 186 patients were taken to the study. $42.5 \%(n=79)$ were male and $56.5 \%(n=105)$ were female and $12.8 \%(n=22)$ were in the neonatal period and 16.8\% ( $n=31)$ were below 1 year of age, 47.3\% ( $n=87)$ were between 1 and 6 years of age, $18.5 \%(n=34)$ were between 7 and 12 years of age and $5,4 \%(n=10)$ of the patients were observed between 13 and 18 years of age. 79\% ( $n=147)$ were satisfied, 18\% ( $n=35)$ were slightly satisfied and 2.1\% $(n=7)$ were not satisfied, when the general satisfaction of the parents with the pediatric emergency department was questioned. A statistically significant relationship was found between the parents' general satisfaction and recommending to their relatives preferring to the pediatric emergency department. $86.4 \%$ of the parents $(n=159)$ stated that they would prefer the pediatric emergency department again.

Conclusions: The pediatric emergency department provides continuous 24-hour service for the patients, and adherence to therapy depends on confidence from satisfaction. Level of physician's medical knowledge, behaviors of healthcare staff, waiting time before the examination, access to the healthcare staff when needed, and satisfaction levels of the resulting time of laboratory and radiology surveys are important factors that affecting general satisfaction of the parents.

Keywords: Pediatric Emergency Department, Parental Satisfaction, Standby time, Doctor Medical Information

\section{INTRODUCTION}

Emergency departments are different from other departments of the hospital. Even if all the beds are full, the patient can not be rejected from the emergency department and the diagnosis and treatment of the emergency patients should be done quickly. Patient satisfaction derpends on; past experiences, future expectations, individual and social values and lifestyle (1). Emergency departments are open to the outside of the hospital, which can be accessed daily and 24 hours a day. Therefore, the separation of the patients to the emergency care service will contribute to the patient's preference for the same hospital in the future. At the same time it is known that the level of satisfaction increases the compliance with the 
Factors Affecting Satisfaction of Parents at Pediatric Emergency Department Admission

proposed treatment and facilitates healing (2). One of World Health Organization (WHO) that has six health system building blocks is the provision of effective, safe and good quality health care services for those in need (3). Previous data indicated that patient satisfaction is more influenced by sociocultural, psychosocial and disease-related characteristics of the patient than by objective quality of care indicators (4). It has been reported that the most effective factor affecting patient satisfaction is the relationship between health service providers and patients (3). The purpose of this study is; To reveal the demographic characteristics of the patients who are referred to the Düzce University Hospital Pediatric Emergency Department, to evaluate the parental satisfaction and to determine the factors affecting the parent satisfaction and the reasons why the parents are satisfied and dissatisfied.

\section{Material AND Methods}

Between February 1, 2017 and April 1, 2017, a total of 186 patients who were accepted to fill out the questionnaire to Düzce University Hospital Pediatric Emergency Department were taken to the study. For inclusion criteria; the parents of the patients referred to the pediatric emergency department were taken. Factors affecting the satisfaction of the parents of the pediatric emergency department and sociodemographic characteristics were investigated. The questionnaires were not made by the service providers, and after the patients' examination procedures were completed, our intern doctors interviewed the patients face to face. Patient relatives were informed before the questionnaire, and approval for the questionnaire was obtained. Ethics committee approval for research was obtained from Düzce University Clinical Research Ethics Committee.

\section{Statistical Analysis}

The SPSS 13.0 (Statistical Package for Social Sciences for Windows) package program was used for statistical analysis. Descriptive statistics and frequency distributions were calculated in accordance with the characteristics of the variables included in the study. Pearson chi-square and Fisher's exact chi-square tests were used to compare the categorical variables.

\section{RESULTS}

A total of 6110 patients were enrolled in the Pediatric Emergency Department between February 1 and April 1, 2017, during the period of the study. The study enrolled 186 patients. Of the patients, $42.5 \%(n=79)$ were males and $56.5 \%(n=105)$ were females. Of the patients, $12 \%(\mathrm{n}=22)$ were in the neonatal period, $16.8 \%(n=31)$ were under 1 year, $47.3 \%(n=87)$ were between 1 and 6 years of age,18.5\% ( $n=34)$ were between 7 and 12 years of age and $5,4 \%(n=10)$ were between 13 and 18 years of age. We found that $94.9 \%$ $(n=167)$ of married and 5,1\% $(n=9)$ of the parents of the pediatric emergency patients were divorced. Considering the educational status, we found that $3.3 \%(n=6)$ of the mothers were not literate, $1.1 \%(n$ $=2$ ) were literate and $50 \%(n=90)$ were primary or junior high school graduates, 33\% $(n=60)$ were high school graduates and $12,6 \%(\mathrm{n}=23)$ were university graduates. We found that $37.7 \%(n=69)$ of the fathers were primary or secondary school graduates, $44.8 \%$ $(\mathrm{n}=82)$ were high school graduates and $16.9 \%(\mathrm{n}=$ 31) were university graduates (Table 1 ).

Table 1. Demographic characteristics of parents of patients

\begin{tabular}{|c|c|c|c|}
\hline Variable & & $\mathrm{n}$ & $\%$ \\
\hline \multicolumn{4}{|l|}{ Gender } \\
\hline & Male & 79 & 42,5 \\
\hline & Woman & 105 & 56,5 \\
\hline \multicolumn{4}{|c|}{ Age group } \\
\hline & Newborn & 22 & 12 \\
\hline & $<1$ year & 31 & 16,8 \\
\hline & 1-6 year & 87 & 47,3 \\
\hline & $7-12$ year & 34 & 18,5 \\
\hline & 13-18 year & 10 & 5,43 \\
\hline \multicolumn{4}{|c|}{ Mother and father } \\
\hline & The married & 167 & 94,9 \\
\hline & Divorced & 9 & 5,11 \\
\hline \multicolumn{4}{|c|}{$\begin{array}{l}\text { Educational status } \\
\text { of mothers }\end{array}$} \\
\hline & Not literate & 6 & 3,3 \\
\hline & Literate & 2 & 1,1 \\
\hline & $\begin{array}{l}\text { Primary / } \\
\text { Secondary School }\end{array}$ & 91 & 50 \\
\hline & High school & 60 & 33 \\
\hline & University & 23 & 12,6 \\
\hline \multicolumn{4}{|c|}{$\begin{array}{l}\text { Educational status } \\
\text { of fathers }\end{array}$} \\
\hline & Not literate & 0 & 0 \\
\hline & Literate & 1 & 0,55 \\
\hline & $\begin{array}{l}\text { Primary / } \\
\text { Secondary School }\end{array}$ & 69 & 37,7 \\
\hline & High school & 82 & 44,8 \\
\hline & University & 31 & 16,9 \\
\hline
\end{tabular}


Factors Affecting Satisfaction of Parents at Pediatric Emergency Department Admission

We were observed that $74.2 \%(n=138)$ of the patients enrolled to the study were within the working hours and $25.3 \%(n=47)$ of the emergency services were outside the working hours. The $61.8 \%(n=115)$ of the pediatric emergency department patients applied to hospital with private vehicles, $33.3 \%(n=62)$ with public transport and 3,7\% (n=7) by ambulances. We found that $74.3 \%(n=130)$ waited less than 15 minutes, $14.9 \%(n=26)$ waited between 15 and 30 minutes, $7.4 \%(n=13) 30$ minutes and 1 hour and $3.4 \%(n=6)$ waited between 1 and 2 hours. Other variables related to the general characteristics of the patients were shown in Table 2 .

Table 2. General characteristics of the parents of the patients

\begin{tabular}{|l|l|l|l|}
\hline Variable & & $\mathbf{n}$ & $\mathbf{\%}$ \\
\hline $\begin{array}{l}\text { Emergency arrival } \\
\text { time }\end{array}$ & & 138 & 74,2 \\
\hline $\begin{array}{l}\text { During working } \\
\text { hours }\end{array}$ & $\begin{array}{l}\text { Out of working } \\
\text { hours }\end{array}$ & 47 & 25,3 \\
\hline $\begin{array}{l}\text { Emergency service } \\
\text { admission form }\end{array}$ & His/Her self & 151 & 81,2 \\
\hline $\begin{array}{l}\text { Pransport to } \\
\text { emergency service }\end{array}$ & The clinic & 30 & 16,1 \\
\hline $\begin{array}{l}\text { in paiting time for } \\
\text { emergency care } \\
\text { treatment }\end{array}$ & Public transport & 62 & 33,3 \\
\hline $\begin{array}{l}\text { Reason for waiting } \\
\text { in emergency } \\
\text { service }\end{array}$ & Private vehicle & 115 & 61,8 \\
\hline & Ambulance & 7 & 3,76 \\
\hline & Standby & 21 & 11,3 \\
\hline & Examination & 25 & 13,4 \\
\hline & Treatment & 115 & 61,8 \\
\hline & & 16 & 8,6 \\
\hline & & 8 & 4,3 \\
\hline & & & \\
\hline & & & \\
\hline & & & \\
\hline & & & \\
\hline & & & \\
\hline & & & \\
\hline
\end{tabular}

\begin{tabular}{|l|l|l|l|}
\hline & $<30$ minute & 65 & 34,9 \\
\hline & $\begin{array}{l}30 \text { minute-1 } \\
\text { hours }\end{array}$ & 13 & 6,99 \\
\hline & $1-2$ hours & 12 & 6,45 \\
\hline & $>2$ hours & 40 & 21,5 \\
\hline $\begin{array}{l}\text { Waiting period } \\
\text { before emergency } \\
\text { service inspection }\end{array}$ & & & \\
\hline & $<15$ minute & 130 & 74,3 \\
\hline & $15-30$ minute & 26 & 14,9 \\
\hline & $\begin{array}{l}30 \text { minute-1 } \\
\text { hours }\end{array}$ & 13 & 7,43 \\
\hline & $1-2$ hours & 6 & 3,43 \\
\hline $\begin{array}{l}\text { Total waiting time } \\
\text { in emergency } \\
\text { service }\end{array}$ & & & \\
\hline & 230 minute & 54 & 29 \\
\hline & $\begin{array}{l}30 \text { minute-1 } \\
\text { hours }\end{array}$ & 21 & 11,3 \\
\hline & $1-2$ hours & 25 & 13,4 \\
\hline & $2-6$ hours & 36 & 19,4 \\
\hline & $6-24$ hours & 17 & 9,14 \\
\hline & $>24$ hours & 10 & 5,38 \\
\hline
\end{tabular}

We observed that 79\% $(n=147)$ were satisfied, $18 \%$ $(n=35)$ were less satisfied and $2.1 \%(n=7)$ were not satisfied when the patients' general satisfaction with the pediatric emergency department was questioned (Figure 1).

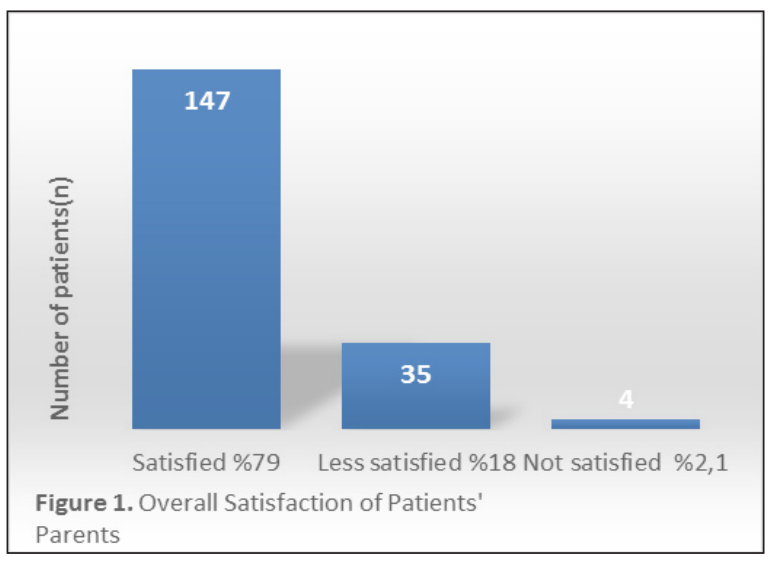

Figure 1. Overall Satisfaction of Patients' Parents

When the patients' satisfaction with the medical knowledge and behavior of the doctors and nurses in the pediatric emergency department were compared with the general satisfaction, we found that there was a statistically significant increase in general patient 
Factors Affecting Satisfaction of Parents at Pediatric Emergency Department Admission

satisfaction level as the doctor's medical knowledge and satisfaction with the nurse's behavior increased (Table 3, Table 4). We observed that the patient's satisfaction with the emergency waiting time and the satisfaction of accessing to the health care personnel in case of need were statistically significant on the overall satisfaction (Table 5, Table 6). We found that the effect of patients on overall satisfaction with the end of the laboratory and radiological examinations was statistically significant. The other parameters of satisfaction of the parents of the patients and the level of satisfaction were given in Table 7.

Table 3. Parents' general satisfaction with medical knowledge of their doctors

\begin{tabular}{|l|l|l|l|l|l|l|l|l|}
\hline & \multicolumn{9}{|l|}{$\begin{array}{l}\text { Level of satisfaction with doctor's } \\
\text { behavior }\end{array}$} \\
\hline $\begin{array}{l}\text { General } \\
\text { satisfaction }\end{array}$ & Yes & \multicolumn{3}{l|}{ Less } & \multicolumn{3}{l|}{ No } & \multicolumn{3}{l|}{ Total } \\
\hline & n & $\%$ & $\mathbf{n}$ & $\%$ & $\mathbf{n}$ & $\%$ & $\mathbf{n}$ & $\%$ \\
\hline Yes & 146 & 78 & 1 & 0,5 & 0 & 0 & 147 & 79,0 \\
\hline Less & 26 & 14 & 7 & 3,8 & 2 & 1,1 & 35 & 18,8 \\
\hline No & 4 & 2,2 & 0 & 0 & 0 & 0 & 4 & 2,2 \\
\hline Total & 176 & 95 & 8 & 4,3 & 2 & 1,1 & 186 & 100 \\
\hline
\end{tabular}

Table 4. Relationship between the behavior of the nurses and the parent's overall satisfaction

\begin{tabular}{|l|l|l|l|l|l|l|l|l|}
\hline & \multicolumn{9}{|l|}{$\begin{array}{l}\text { Level of satisfaction with nurse } \\
\text { behavior }\end{array}$} \\
\hline $\begin{array}{l}\text { General } \\
\text { satisfaction }\end{array}$ & \multicolumn{7}{|l|}{ Yes } & \multicolumn{3}{|l|}{ Less } & \multicolumn{3}{l|}{ No } & \multicolumn{3}{l|}{ Total } \\
\hline & n & $\%$ & n & $\%$ & n & $\%$ & n & $\%$ \\
\hline Yes & 145 & 78 & 2 & 1,1 & 0 & 0 & 147 & 79 \\
\hline Less & 25 & 13 & 7 & 3,8 & 3 & 1,6 & 35 & 18,8 \\
\hline No & 4 & 2,2 & 0 & 0 & 0 & 0 & 4 & 2,15 \\
\hline Total & 174 & 94 & 9 & 4,8 & 3 & 1,6 & 186 & 100 \\
\hline
\end{tabular}

Table 5. Relationship between parental satisfaction and emergency waiting period

\begin{tabular}{|c|c|c|c|c|c|c|c|c|}
\hline \multirow{3}{*}{$\begin{array}{l}\text { General } \\
\text { satisfaction }\end{array}$} & \multicolumn{8}{|c|}{$\begin{array}{l}\text { Level of satisfaction with the waiting } \\
\text { period }\end{array}$} \\
\hline & \multicolumn{2}{|l|}{ Yes } & \multicolumn{2}{|c|}{ Less } & \multicolumn{2}{|l|}{ No } & \multicolumn{2}{|c|}{ Total } \\
\hline & $\mathbf{n}$ & $\%$ & $\mathbf{n}$ & $\%$ & $\mathbf{n}$ & $\%$ & $\mathbf{n}$ & $\%$ \\
\hline Yes & 129 & 69 & 14 & 7,53 & 3 & 1,6 & 146 & 78 \\
\hline Less & 21 & 11 & 7 & 3,76 & 8 & 4,3 & 36 & 19 \\
\hline No & 2 & 1,1 & 2 & 1,08 & 0 & 0 & 4 & 2,2 \\
\hline Total & 152 & 82 & 23 & 12,4 & 11 & 5,9 & 186 & 100 \\
\hline
\end{tabular}

Table 6. Relationship between access to healthcare personnel in case of need and parental satisfaction

\begin{tabular}{|l|l|l|l|l|l|l|l|l|}
\hline & \multicolumn{9}{l|l|}{$\begin{array}{l}\text { Level of satisfaction with reaching } \\
\text { healthcare personnel }\end{array}$} \\
\hline $\begin{array}{l}\text { General } \\
\text { satisfaction }\end{array}$ & \multicolumn{3}{|l|}{ Yes } & \multicolumn{3}{|l|}{ Less } & \multicolumn{3}{|l|}{ No } & \multicolumn{2}{l|}{ Total } \\
\hline & n & $\%$ & n & $\%$ & n & $\%$ & n & $\%$ \\
\hline Yes & 128 & 68,8 & 19 & 10 & 2 & 1,1 & 149 & 80 \\
\hline Less & 24 & 12,9 & 6 & 3,2 & 5 & 2,7 & 35 & 19 \\
\hline No & 2 & 1,08 & 0 & 0 & 0 & 0 & 2 & 1,1 \\
\hline Total & 154 & 82,8 & 25 & 13 & 7 & 3,8 & 186 & 100 \\
\hline
\end{tabular}

Table 7. Variables related to parental satisfaction

\begin{tabular}{|l|l|l|l|}
\hline Parameters & & $\mathbf{n}$ & $\mathbf{\%}$ \\
\hline \multirow{2}{*}{$\begin{array}{l}\text { Reception, counseling } \\
\text { and referral services were } \\
\text { generally good. }\end{array}$} & Yes & 151 & 81,2 \\
\cline { 2 - 4 } & Less & 24 & 12,9 \\
\cline { 2 - 4 } & No & 11 & 5,91 \\
\hline \multirow{3}{*}{$\begin{array}{l}\text { The waiting rooms were } \\
\text { relaxed. }\end{array}$} & Yes & 104 & 56,2 \\
\cline { 2 - 4 } & Less & 50 & 27 \\
\cline { 2 - 4 } & No & 31 & 16,8 \\
\hline \multirow{3}{*}{$\begin{array}{l}\text { I was pleased with the } \\
\text { timing of the lab tests. }\end{array}$} & Yes & 128 & 72,7 \\
\cline { 2 - 4 } & Less & 30 & 17 \\
\cline { 2 - 4 } & No & 18 & 10,2 \\
\hline \multirow{2}{*}{$\begin{array}{l}\text { I was satisfied with the } \\
\text { timing of the radiology } \\
\text { examinations. }\end{array}$} & Yes & 131 & 78,4 \\
\cline { 2 - 4 } & Less & 22 & 13,2 \\
\cline { 2 - 4 } $\begin{array}{l}\text { Emergency service workers } \\
\text { took care of our personal } \\
\text { privacy. }\end{array}$ & Yes & 14 & 8,38 \\
\cline { 2 - 4 } & Less & 20 & 11,1 \\
\cline { 2 - 4 } & No & 3 & 1,67 \\
\hline \multirow{2}{*}{$\begin{array}{l}\text { Emergency service was } \\
\text { clean. }\end{array}$} & Yes & 115 & 62,2 \\
\cline { 2 - 4 } & Less & 51 & 27,6 \\
\cline { 2 - 4 } & No & 19 & 10,3 \\
\hline \multirow{2}{*}{$\begin{array}{l}\text { The conditions of the } \\
\text { emergency room were good. }\end{array}$} & Yes & 107 & 57,5 \\
\cline { 2 - 4 } & Less & 56 & 30,1 \\
\cline { 2 - 4 } & No & 23 & 12,4 \\
\hline \multirow{2}{*}{ A } & & & \\
\hline
\end{tabular}

A statistically significant relationship was found between the parents' preferences for visiting or recommending the pediatric emergency department to their relatives and their general satisfaction. $86.4 \%$ of the families $(n=159)$ stated that they would prefer the pediatric emergency department again in the future (Figure 2). 
Factors Affecting Satisfaction of Parents at Pediatric Emergency Department Admission

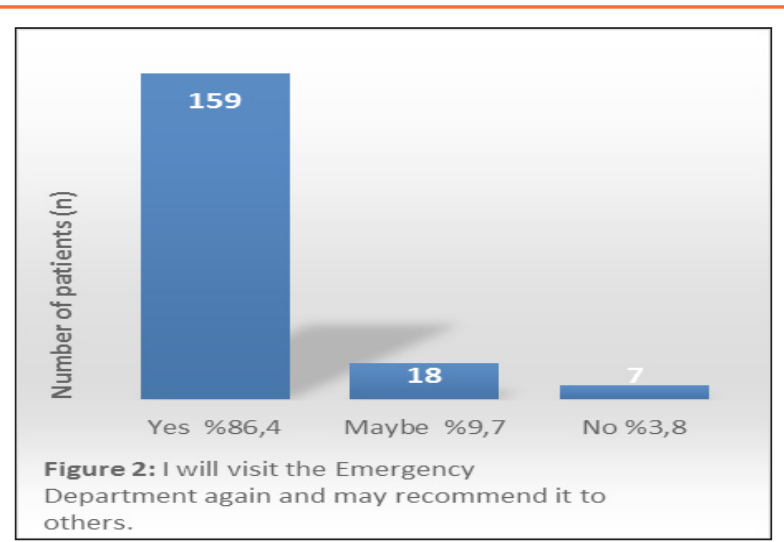

Figure 2. I will visit the Emergency Department again and may recommend it to others.

\section{DISCUSSION}

The quality perceived by the parents in the Pediatric Emergency Department and satisfaction as a function of the expected quality occurs. Before parents receive service there are certain expectations and certain perceptions are formed after service presentation. Parents determine whether it is satisfied as a result of the comparison between the quality it perceives and the quality it expects (5). The most important factors in satisfaction can be summarized as information, orientation, speed of service, interest and kindness, empathy, psychosocial support, competence of service providers, appropriateness of timeliness of medical tests and overall quality (6).

Many studies on patient satisfaction have been made in our country, and according to these studies we have a sample volume in the middle order. The 135 patients in Marmara University Hospital in 2008 and 117 patients in another study conducted by Ozcan et al. in Silvan State Hospital in 2008, 473 patients in a study of Apay et al. 180 patients who were referred to the Emergency Department of the Faculty of Medicine of Afyon Kocatepe University by Oruç et al. were evaluated in 2014 (7-9,2). In our study, 186 patients were enrolled. However, the number of studies on parental satisfaction in the pediatric emergency department is low, and when the factors affecting parental satisfaction in pediatric emergency services will become clearer.

When we look at the overall satisfaction rates, the level of patient satisfaction in a study conducted in 2012 in Ethiopia was 86.7\%, in Saudi Arabia in a study conducted in 2011, 70.4\%, Akkaya et al. in the study conducted byUludağUniversityHospitalin2008,93.3\% and Așlıoğlu et al. In the Ondokuz Mayıs University Hospital in 2008, it was seen as $74.6 \%$ in the study about the level of parental satisfaction in the pediatric emergency department $(1,3,4,10)$. In our study, it was determined that a great majority of parents $(97 \%$ satisfied, $18 \%$ less satisfied) were satisfied with the pediatric emergency department when their general satisfaction levels were questioned during their stay in the pediatric emergency department. The high level of satisfaction in our work and in other studies conducted in our country indicated that the quality of the patient health care is better in our country.

Waiting time is an important component of patient satisfaction (4). In a study conducted in our country, pre-examination waiting times were 74.8 minutes, 51.1 minutes, and 129.7 minutes (1). In our study, $74.3 \%(n=130)$ of the patients were waiting less than 15 minutes before examination, satisfaction level with respect to waiting times was $94.4 \%(n=175)$, it was seen that satisfaction with statistical latency was significant on parents' overall satisfaction. The waiting period in our study was observed to be less than the other three studies in our country.

As a result of our research we determined that behavior and medical knowledge and behavior of doctors and nurses in pediatric emergency department, access to healthcare staff when needed, and of obtaining early the results of laboratory and radiology tests affect parents' overall satisfaction. The most important reasons for the dissatisfaction of the patients in the emergency department are the inappropriate attitude and clothing of the physician, the lack of knowledge on them, the inadequate communication skills, the negativity of the physical environment of the emergency department and the long waiting periods. Nurses also need to have good communication with the patient because the nurse's attitudes and behaviors are also a factor that has a significant effect on the overall satisfaction of patients (1). In our study, we found that parents' satisfaction level of emergency nurses was $94 \%$, and the effect of nursing behavior, medical care and experience on overall satisfaction was statistically significant. Waiting long periods in laboratory, imaging and other ancillary services increase the length of stay in patients' emergency services, leading to dissatisfaction for parents. It has been reported that 
the use of technologies that accelerated laboratory services in Konca and Ceyhan's work shortened the waiting time of patients in emergency services $(1,11)$. In our study, the satisfaction of the patients with respect to the duration of the end of the laboratory and radiological examinations was found to be influential on the parents' overall satisfaction. The dissatisfaction of parents increased as the duration of the expiration of the investigations were prolonged.

It is stated in the literature that patients usually apply to the emergency unit because they perceive their situation as urgent or because the emergency unit is close to home, to a shorter time for examination, not to find a place in the related policlinics or to make a prescription printing and parenteral application or not to receive care from other hospital units (6). In our study, when the education levels of the parents who applied for emergency services, it was found that $50 \%$ of mothers $(n=91)$ were primary school or junior high school graduates and 33\% ( $=60)$ were high school graduates, of the fathers $37,7 \%(n=69)$ were elementary or junior high school graduates and $44,8 \%$ ( $n=82$ ) were high school graduates. We observed that the education level of the patients who preferred the emergency department in our study was low and medium level and we observed that people with high education level did not unnecessarily occupy the emergency department.

When looking at the preference for emergency department, Topuz and his colleagues determined that $41.4 \%$ of the patients who applied in their studies would prefer again and that the Preference and friends preferred $70.7 \%(12,13)$. In our study, we observed that $86.4 \%(n=159)$ of the parents would prefer the pediatric emergency department again and recommend it to their relatives.

An important issue to be aware of, the satisfaction of the parents of the patients provides the trust in the service first. Studies show that trust is an indispensable element in establishing a therapeutic relationship and has a significant effect on compliance with care (14).

\section{ConCLUSIONS}

The pediatric emergency department provides continuous 24-hour service for the patients who were admitted, and the compliance of the treatment depends on the confidence from the satisfaction. The physician's medical knowledge, the behavior of the nurse, the waiting period before the emergency care visit, the access to the healthcare staff if necessary, and the satisfaction level of the laboratory and radiology examinations are important factors affecting the overall satisfaction of the parents. When all these results were evaluated together, it should be targeted to relatively low areas of parental satisfaction and high satisfaction levels should be maintained. Hospital administrators should improve to in order to get healthcare future facilities satisfactions of parents.

\section{REFERENCES}

[1] Gültekin Akkaya E, Bulut M, Akkaya C. [The Factors Affecting the Level of Patients' Satisfaction of the Applicants for Emergency Service]. Tr J Emerg Med 2012;12(2):62-8.

[2] Akpınar Oruç O, Üzel Taş H. [Level of Satisfaction of Patients Admitting to Emergency Room]. Kocatepe Medical Journal 2014;15(2):131-6.

[3] Worku M, Loha E. Assessment of client satisfaction on emergency department services in Hawassa University Referral Hospital, Hawassa, Southern Ethiopia. BMC Emergency Medicine 2017;17:21.

[4] Abolfotouh MA, Al-Assiri MH, Alshahrani RT, Almutairi ZA, Hijazi RA, Alaskar AS. Predictors of patient satisfaction in an emergency care centre in central Saudi Arabia: a prospective study. Emerg Med J 2017;34(1):27-33.

[5] Tükel B, Acuner AM, Önder ÖR, Üzgül A. [A Study on Inpatient Satisfaction in İbn -i Sina Hospital of Ankara University]. Journal of Ankara University Faculty of Medicine 2004;57(4):205-214.

[6] Topal FE, Şenel E, Topal F, Mansuroğlu C. [A patients' satisfaction study: Satisfaction levels of the patients admitted to emergency clinic of a state hospital]. Cumhuriyet Med J 2013; 35: 199205.

[7] Önsüz MF, Topuzoğlu A, CöbekUC, ErtürkS, Yılmaz F, Birol S. [Satısfactıon levels of hospitalızed patients in a university hospital in Istanbul]. Marmara Medical Journal 2008;21(1):33-4. 
Factors Affecting Satisfaction of Parents at Pediatric Emergency Department Admission

[8] Özcan M, Özkaynak V, Toktaş İ. [The Satisfaction Levels of Outpatients in Silvan State Hospital Puplic]. Dicle Medical Journal 2008;35(2):96101.

[9] Apay SE, Arslan S. [Satisfaction Level Of Inpatient in an University Hospital]. TAF Preventive Medicine Bulletin 2009; 8(3):239-44.

[10] Aşılıoğlu N, Akkuş T, Baysal K. [Investigetion of parents' satisfaction and the causative factors in pediatric emergency department]. Turk J Emerg Med 2009;9(2):65-72.

[11] Konca GE, İlhan M, Bumin MA. [The expectations of inpatients with regard to the hospital employees and hospital services, and an evaluation of the meeting of these expectations summary].Gazi Medical Journal 2006;17(3):160-70.

[12] Topuz Ş, Erdem Y, Akdemir H. [Satisfaction Levels of Inpatients in a State Hospital] Duzce Medical Journal2014; 16(2): 31-34.

[13] Önsüz MF, Topuzoğlu A, Cöbek UC, ErtürkS, Yılmaz F, Birol S. [Satisfaction levels of hospitalized patients in a university hospital in Istanbul]. Marmara Medical Journal. 2008; 21(1): 33-49.

[14] Silva PL, Paiva L, FariaVB, Ohl RIB, Chavaglia SRR. Triage in an adult emergency service: patient satisfaction. Rev Esc Enferm USP 2016;50(3):427-432.

Citation: Muhammet Mesut Nezir ENGİN, Ramazan Cahit Temizkan, Merve Aslantaş, Nursel Büyük Önder Kılıçaslan, Yunus Şengün, Kenan Kocabay. Factors Affecting Satisfaction of Parents at Pediatric Emergency Department Admission. Archives of Emergency Medicine and Intensive Care. 2018; 1(1): 38-44.

Copyright: (C) 2018 Muhammet Mesut Nezir ENGİN, Ramazan Cahit Temizkan, Merve Aslantaş, Nursel Büyük Önder Kılıçaslan, Yunus Şengün, Kenan Kocabay. This is an open access article distributed under the Creative Commons Attribution License, which permits unrestricted use, distribution, and reproduction in any medium, provided the original work is properly cited. 